\title{
Ice-core insights into the flow and shut-down of Ice Stream C, West Antarctica
}

\author{
Donald E. VOIGT, Righard B. ALLEY, Sridhar ANANDAKRiShNAN, Matthew K. SPENGER \\ EMS Environment Institute and Department of Geosciences, The Pennsylvania State University, University Park, PA 16802-7501, U.S.A.
}

E-mail:voigt@geosc.psu.edu

\begin{abstract}
Vigorous flow of central regions of Ice Stream C, West Antarctica, near the UpC camp ended about the year 1830, based on analysis of a firn and ice core taken at the camp. Ice-stream flow was characterized by repeated fracturing and healing, probably subsurface, especially near the onset of streaming flow. High longitudinal stresses caused fracturing, recrystallization of the ice and elongation of bubbles, and enhanced densification rates of high-density firn indicating power-law-creep behavior.
\end{abstract}

\section{INTRODUCTION}

TheWest Antarctic ice sheet drains into the Ross Sea primarily through ice streams crossing the Siple Coast (e.g. Alley and Bindschadler, 2001). Within the past $\sim 150$ years $(130 \pm 25$ years from Retzlaff and Bentley, 1993), Ice Stream C (Fig. 1; Alley and Bentley, 1988) slowed from a rate probably similar to that now observed in the neighboring Ice Stream D and Whillans Ice Stream (formerly known as Ice Stream B), about $500 \mathrm{~m} \mathrm{a}^{-1}$, to a rate of tens of meters per year or less. Possible reasons for the slow-down are discussed by, for example, Anandakrishnan and Alley (1997), Tulaczyk and others (2000), Anandakrishnan and others (2001), Price and others (2001) and Whillans and others (2001).

The ice contains information on the flow of Ice Stream C and its shut-down. To read this record, a $134 \mathrm{~m}$ long, $10.2 \mathrm{~cm}$ diameter firn and ice core was collected at the UpC Camp

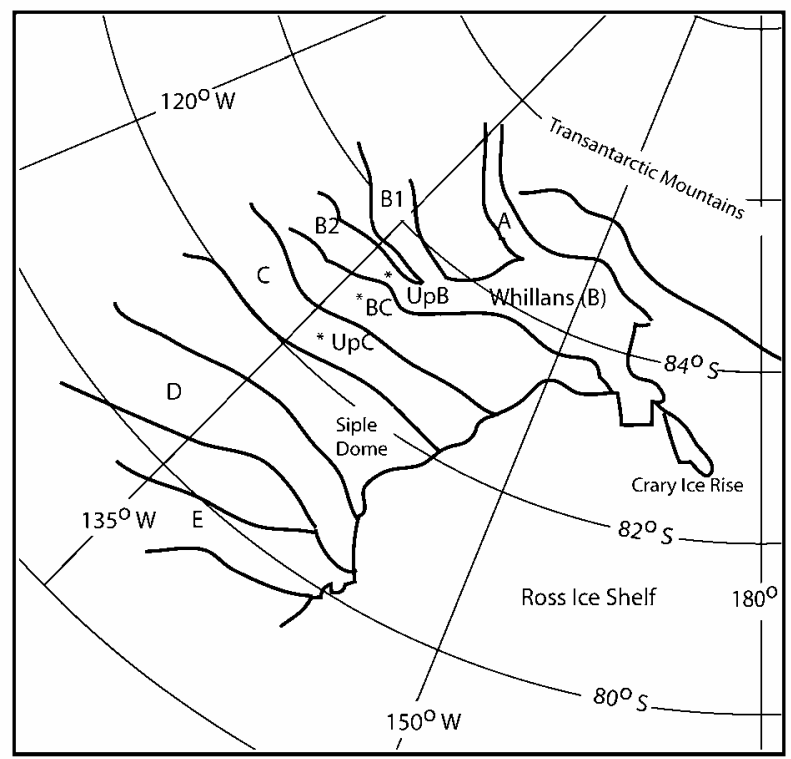

Fig. 1. Location sketch map of the Siple Coast of West Antarctica showing general area of ice streams and location of cores taken from UpC, UpB, BC and Siple Dome. during the 1996/97 season by one of us (D.E.V.) with the Polar Ice Coring Office (PICO). The borehole was located at $82^{\circ} 26.36^{\prime} \mathrm{S}, 135^{\circ} 58.30^{\prime} \mathrm{W}$, where the ice velocity is $25 \mathrm{ma}^{-1}$ (based on global positioning system measurements over the

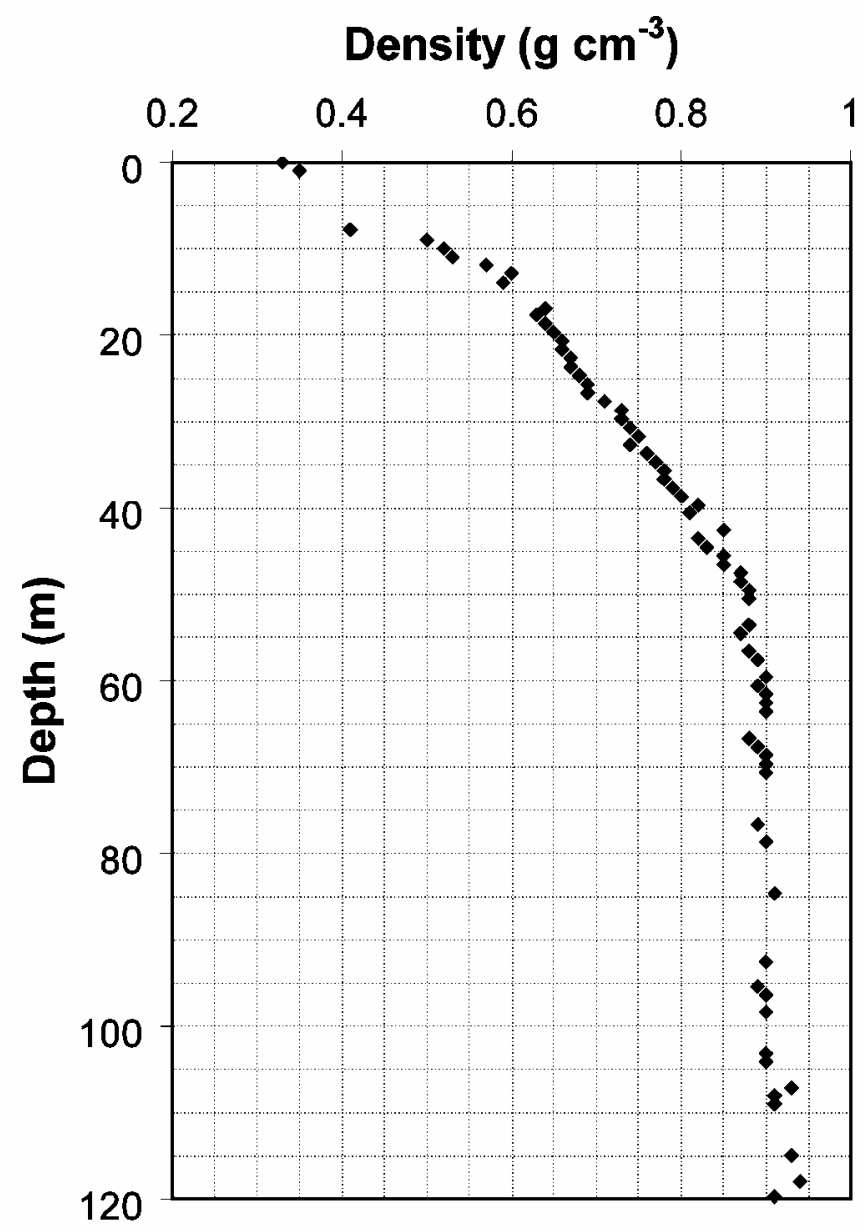

Fig. 2. Density-depth data from UpC core. Data points at surface and $1 \mathrm{~m}$ depth were calculated by averaging the measured densities of snow samples taken from a pit. Other points represent the measured density of the core determined in the field. Depth is taken as the top of a sample interval. 


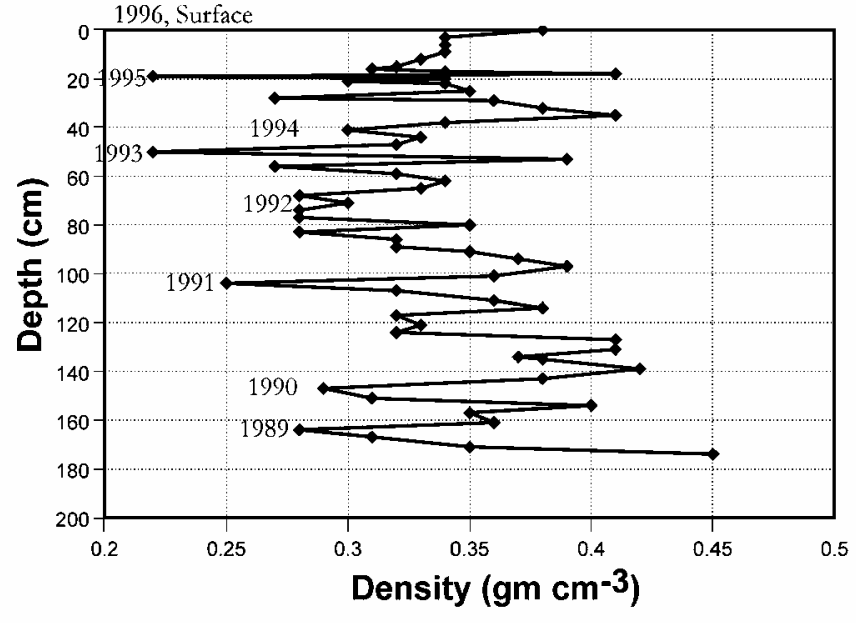

Fig. 3. Density-depth relationships in $1.7 \mathrm{~m}$ snow pit. Density is calculated from weight of firn sample taken with snowdensity box ( see text). Years indicate summer layers based on visual observation in the snow pit and measured density. The surface represents the summer of 1996.

period 1994-96). Values for the ice thickness in this area range from $1080 \mathrm{~m}$ as measured by airborne radar (Retzlaff and others, 1993) to around $1200 \mathrm{~m}$ as measured in a borehole (Kamb, 2001), these measurements not being co-located. Densities of ice-core samples and of firn samples from a $1.7 \mathrm{~m}$ snow pit were measured in the field. Additional analyses of the core were conducted at the U.S. National Ice Core Laboratory (NICL), Denver, Colorado, during summer 1997.

\section{OBSERVATIONS}

\section{Depth-density profile}

Density of the core was calculated using the length, diameter and weight of each piece of core measured in the field prior to packing for storage and shipment. Figure 2 shows density as a function of depth; minor data gaps at shallow depth are related to core quality. The approximate pore close-off density of $830 \mathrm{~kg} \mathrm{~m}^{-3}$ is reached at $42 \mathrm{~m} \mathrm{depth}$. This density is reached at $33 \mathrm{~m}$ in the $\mathrm{UpB}$ core from Whillans Ice Stream, and $52 \mathrm{~m}$ in the BC core (labeled UpBC in Fig. 1), sites with temperature and accumulation rate similar to UpC (Alley and Bentley, 1988).

The shallowest data points in Figure 2 summarize the snow-pit densities plotted in Figure 3. The density at each point was determined from the weight of a measured volume of firn sampled from the snow-pit wall with snowdensity boxes. Two boxes were used, 1 and $3 \mathrm{~cm}$ thick, with volumes of 33 and $99 \mathrm{~cm}^{3}$, respectively, and firn samples were removed so as to encompass visibly homogeneous layers. The calculated densities of the samples were then averaged over the intervals $0-1$ and $1-1.7 \mathrm{~m}$ for the top two data points in Figure 2. Also shown in Figure 3 are the summer annual layers picked by a combination of observation of the snow wall in the pit and measured firn densities (see discussion below). Note that while the summers of 1994 and 1992 do not show low-density spikes, observations in the pit show these to be summer layers.

\section{Annual layers}

Annual layers in the core were counted during visual exam-

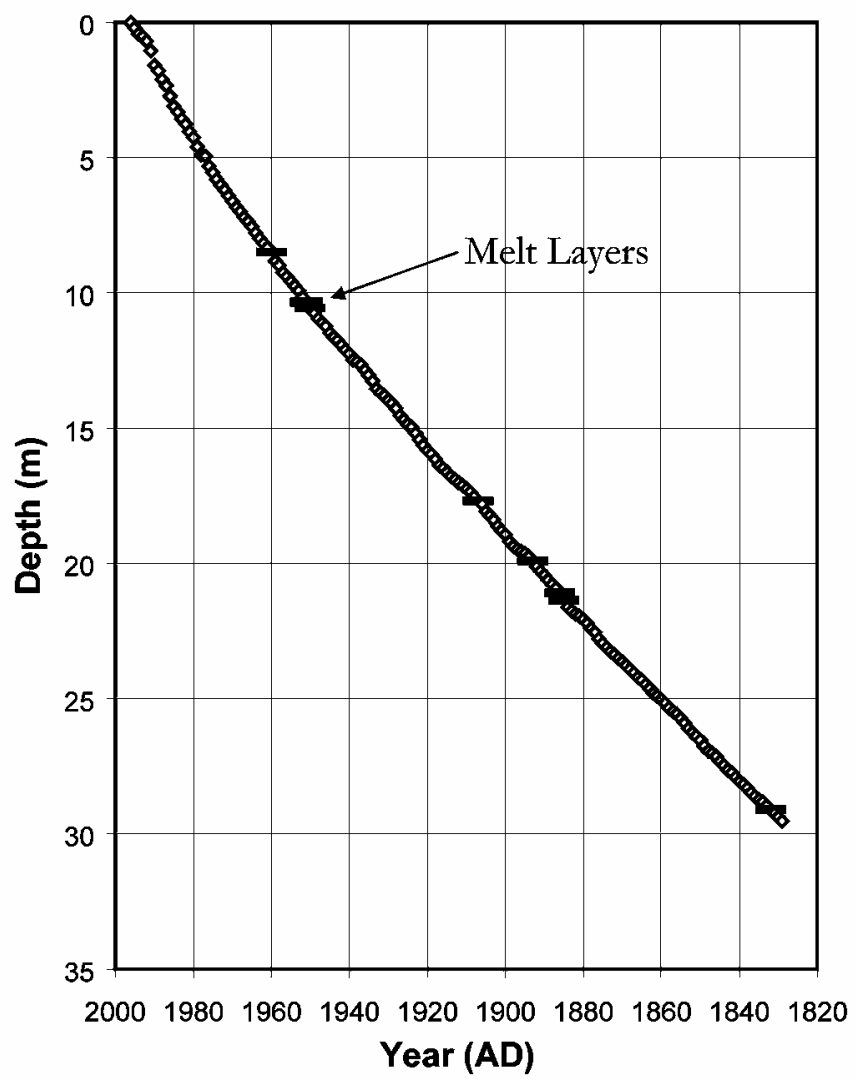

Fig. 4. Age-depth relationship of UpC core obtained by summing annual layers as determined by visual stratigraphy to a depth where annual layers were no longer discernible. Solid lines indicate melt layers observed in the core during visual logging. Deeper melt layers ( to $50 \mathrm{~m}$ ) in ice of uncertain age are not shown.

ination as the core was processed at NICL. Identification of annual layers was made on a freshly cut and planed surface of the core, bisected lengthwise. Examination of the core on a light table showed alternating layers of coarse-grained, low-density firn or ice that represent summer snow, and fine-grained, more homogeneous firn or ice that represents densely packed snow laid down in winter (Alley, 1988). Figure 4 shows the depth-age relationships to $29.7 \mathrm{~m}$ depth, corresponding to an age of 168 years (the year 1828). Estimated accuracy is $\pm 5 \%$, based on ongoing studies at Siple Dome, which has temperature, accumulation rate and visible strata similar to those of Ice Stream C (personal communication from K. Taylor, 2001). Beginning at $29.7 \mathrm{~m}$ depth, an approximately $3 \mathrm{~m}$ thick layer was encountered that appears to be a break in the annual layers. This layer is rather homogeneous, contains abundant small bubbles and, as described below, may be a crevasse fill. Below this feature, sections of ice again display countable annual layers, but the count continuity is lost, and layers become less distinct with increasing depth.

Visual inspection of the core during processing allowed identification of melt layers to $50 \mathrm{~m}$. Because of the break in annual layers, however, dating of the melt layers was only possible to $29.7 \mathrm{~m}$ as shown in Figure 4. Melt layers should have been visible in the bubbly ice deeper than $50 \mathrm{~m}$, but were not observed. They were identified as bubble-free zones within the core. They usually have irregular shape, are parallel to annual layers and may form lenses that pinch out. The melt layers observed in the core varied in thickness from 5 to $20 \mathrm{~mm}$.

The recent accumulation rate was estimated from examination of the firn in a back-lit snow pit, together with the 


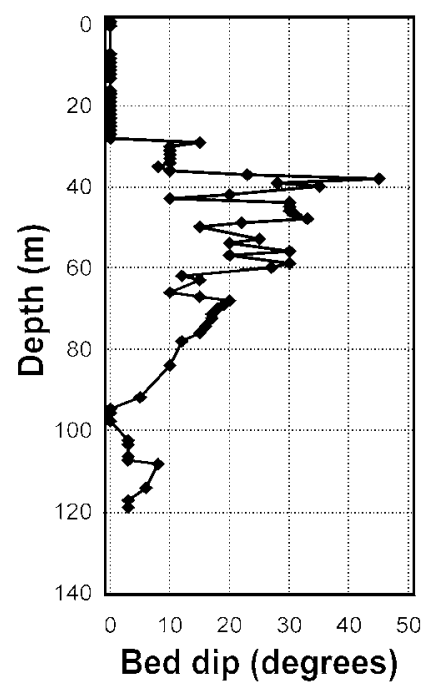

a

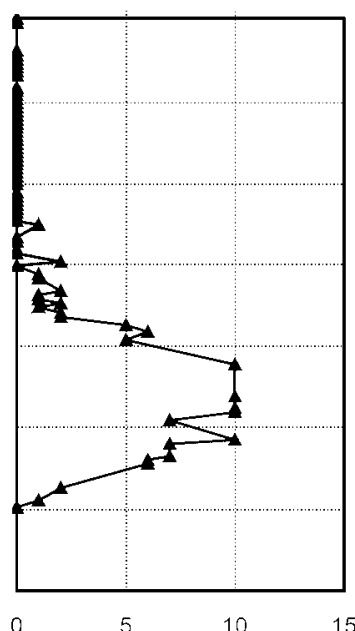

Number of fractures

b
Fig. 5. (a) Angle of bed dip (degrees from horizontal) vs depth; (b) number of fractures per meter of core vs depth.

density data. The value of $8.77 \mathrm{~cm} \mathrm{a}^{-1}$ of ice equivalent over the 7 years (1989-96) in the upper $1.7 \mathrm{~m}$ matches closely with reported accumulation rates of $8.6 \mathrm{cma}^{-1}$ at $\mathrm{UpB}$ and
$9.0 \mathrm{~cm} \mathrm{a}^{-1}$ at BC for the time period $1978-85$ from Alley and Bentley (1988).

\section{Electrical conductivity measurement and dielectric} property measurement

During processing of the core at NICL, electrical conductivity measurement (ECM) (Taylor and others, 1992) and dielectric property measurement (DEP) (Moore and Paren, 1987) logs were taken. The ECM record shows one large, $\sim 100 \mathrm{~mm}$ thick spike in conductivity, indicating high acidity at $81 \mathrm{~m}$ depth. The DEP, which measures total ionic concentration in the core, also shows this spike at $81 \mathrm{~m}$, and another at $63 \mathrm{~m}$ that has no equivalent in the ECM record.

\section{Core characterization}

Layers above the probable crevasse fill (29.7-33 m) are nearly horizontal, whereas deeper layers are inclined, as shown in Figure 5a. Dips increase to a maximum of about $45^{\circ}$ at $40 \mathrm{~m}$ depth, and then generally decrease toward the bottom of the core.

Features that we interpret as the traces of healed fractures occur deeper than about $50 \mathrm{~m}$ (Fig. 6). A fracture trace is expressed as a plane of tiny bubbles bounded by a nearly bubble-free zone typically a few millimeters across. Occasionally

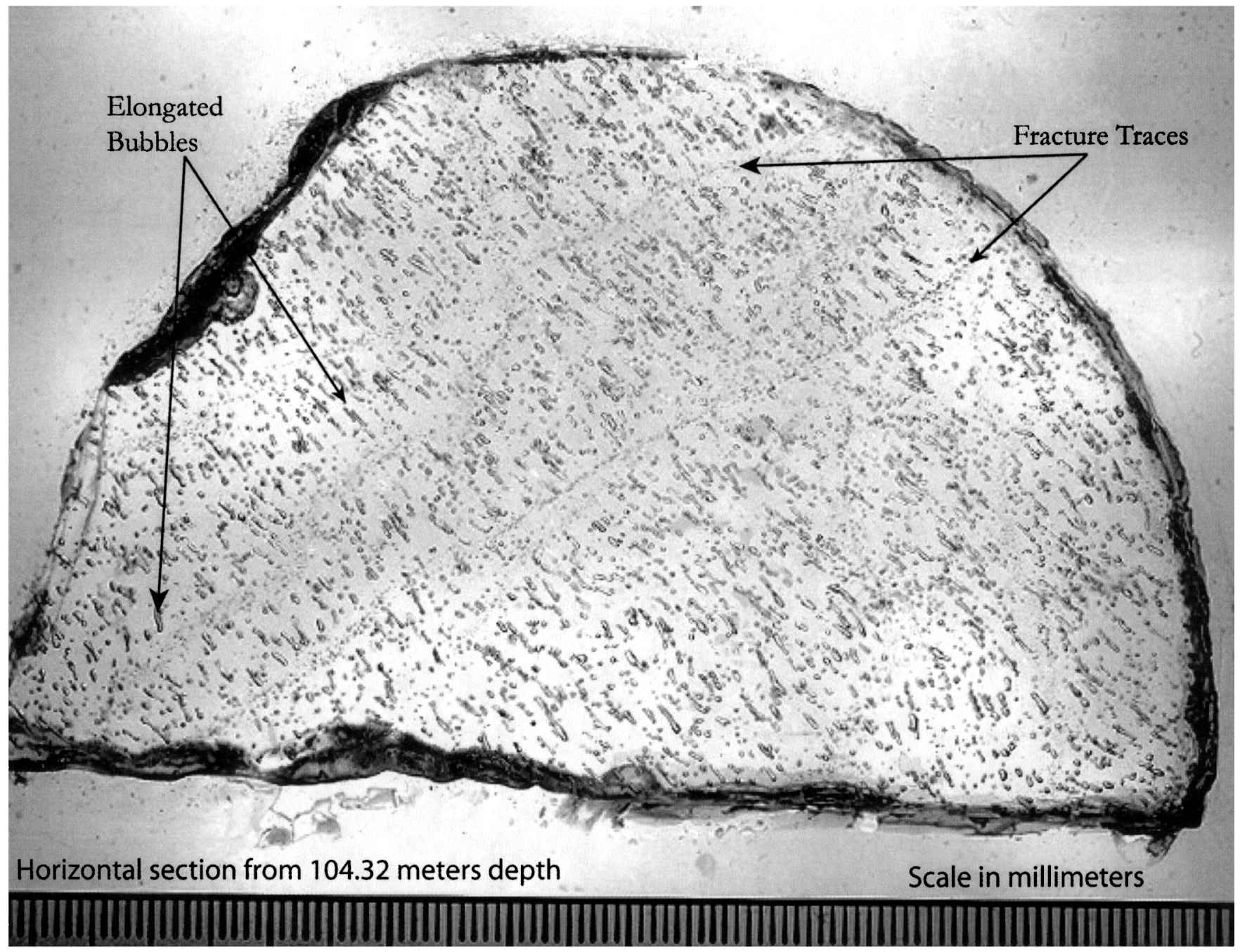

Fig. 6. Photograph of a section from the UpC core at $104.32 \mathrm{~m}$ depth looking down the axis of the core ( sample for thin section was removed after core was cut in half for archiving). Note orientation of the elongated bubbles and fracture traces. Because of the thickness of the section and the slight inclination of the feature, some subsurface bubbles appear in the bubble-free zone around the fracture trace described in the text. The photo was taken by 7. 7. Fitzpatrick. 
the central plane of the original fracture is marked by larger disk-shaped bubbles aligned parallel to the fracture. These fractures typically are nearly vertical, and as shown in Figure 6 , there is a prominent and pervasive bubble elongation normal to the fracture traces and probably linked to alongflow stretching (Alley and Fitzpatrick, 1999). Some fractures appear to have split or joined during propagation, and lozenge-shaped pieces of ice can be isolated between fractures. These pieces are roughly $5-50 \mathrm{~mm}$ wide and $50-500 \mathrm{~mm}$ long. In some cases, later fractures are observed to cross-cut earlier ones, or are inferred to have exploited pre-existing weakness by reopening former fractures to produce zones with more than one "central" plane of bubbles.

The full three-dimensional nature of these fractures cannot be characterized in a single, $100 \mathrm{~mm}$ diameter core, but no strong depth trends were observed in dips or waviness of the fracture traces. Thus, simply counting the number of separate fracture traces in a core segment provides a useful estimate of fracture density. As shown in Figure 5b, these fracture features were not observed above $50 \mathrm{~m}$ or below $120 \mathrm{~m}$, and exhibit a broad peak in occurrence near $90 \mathrm{~m}$ depth.

\section{INTERPRETATION}

This UpC core contains an especially rich suite of physical features. These must in some fashion record characteristics of the flow and shut-down of the ice stream, as well as changes since then.

\section{Visible strata}

The layering is apparently annual and horizontal to $29.7 \mathrm{~m}$ depth, approximately the year 1828 ( \pm 8 years estimated error). This corresponds well with the timing of the shutdown of Ice Stream C based on previous studies (Retzlaff and Bentley, 1993). The ECM and DEP peaks at $81 \mathrm{~m}$ probably represent volcanic fallout; however, no ash was evident in visible inspection. Based on prominence and approximate age, this $81 \mathrm{~m}$ peak is possibly the fallout from the eruption of El Chichón, Mexico, in 1259 (Palais and others, 1992). The origin of the DEP peak at $63 \mathrm{~m}$ is unknown and may simply represent the transportation inland of sea salts by a strong coastal storm.

The $3 \mathrm{~m}$ zone of relatively homogeneous-appearing ice just below $29.7 \mathrm{~m}$ depth that shows a lack of annual layers and numerous small bubbles is consistent with rapid infilling of a crevasse by fine-grained drift snow. Finer grains, hence smaller bubbles (Gow, 1968), likely reflect both the shorter time that passed for burial to given depth for crevasse fill compared to normal firn, and the shorter time that the crevasse fill spent in the very shallow zone of strong temperature gradients where grain growth is greatly accelerated (Gow, 1975). We cannot tell whether this fine-bubbled, homogeneous zone represents complete infilling of the crevasse (which then would have been approximately $6-7 \mathrm{~m}$ deep, allowing for twofold compaction during firn densification), or whether the initial crevasse extended deeper and the drill has exited through the side of the crevasse. Non-zero dips are observed in beds at the bottom of the crevasse fill, but are not especially steep (Fig. 5a).

\section{Density profile}

The depth-density profiles of the UpB core on active Whillans Ice Stream and of the adjacent, slow-moving ridge

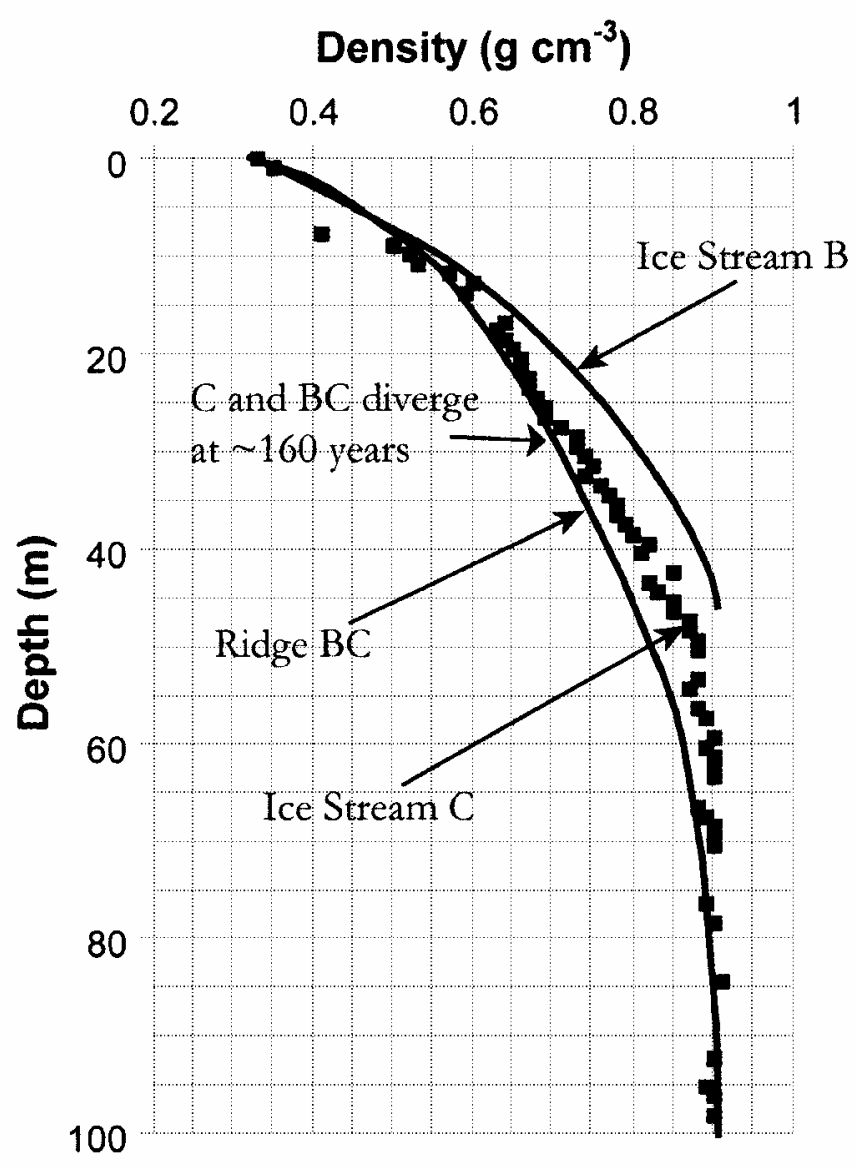

Fig. 7. Depth-density relationships of UpC core (points) overlain by curves from Alley and Bentley (1988) for BC and $U p B$.

BC (Fig. 7) were indistinguishable from each other for densities less than $\sim 550 \mathrm{~kg} \mathrm{~m}^{-3}$, but densification proceeded faster on the ice stream at greater depths (Alley and Bentley, 1988). One interpretation of this is that ice-flow stresses in the ice stream accelerate densification only at densities higher than $\sim 550 \mathrm{~kg} \mathrm{~m}^{-3}$. Previous work (Alley, 1987) has suggested that densification at low densities is dominated by grain-boundary sliding, which would be a linear-viscous process unaffected by ice-flow stresses. At higher densities, power-lawcreep densification is believed to be dominant and would be affected by ice-flow stresses (Duval, 1985; Ebinuma and Maeno, 1985; Alley, 1987; Alley and Bentley, 1988). Our data are fully consistent with this view, presuming that the existence of the few meters of probable crevasse fill has not greatly affected the densification profiles. The shallow part of the $\mathrm{UpC}$ profile is similar to that from ridge $\mathrm{BC}$, except for the shallowest part of the core where there were sampling problems. Starting at a point about 160 years before coring, at a core depth of $28.6 \mathrm{~m}$, the profile at $\mathrm{UpC}$ exhibits a density increase with depth that becomes more similar to ice-stream values such as those seen from $\mathrm{UpB}$. This change appears to occur over a period of 7-14 years, as represented by $1-2 \mathrm{~m}$ of core. Inspection shows (and has been validated using a firndensification model of Spencer and others (2001)) that one can produce a profile similar to that observed at $\mathrm{UpC}$ by starting with the steady, active-ice-stream UpB profile, and then burying it and densifying it along a "normal" ridge-type BC profile, beginning at the time of Ice Stream C shut-down. The non-steady curve in such an experiment would overlie the $\mathrm{UpB}$ and BC profiles at low density $\left(<550 \mathrm{~kg} \mathrm{~m}^{-3}\right)$ at all times, and would evolve from the $\mathrm{UpB}$ to the $\mathrm{BC}$ profile over 
time at densities between $550 \mathrm{~kg} \mathrm{~m}^{-3}$ and that of ice, giving an intermediate profile today as observed. We thus suggest that $\mathrm{UpC}$ had a depth-density profile similar to that of $\mathrm{UpB}$ prior to shut-down, and is now developing a profile similar to that of BC. Furthermore, the extra stresses on ice streams compared to ridges appear to promote rapid densification at densities above about $550 \mathrm{~kg} \mathrm{~m}^{-3}$ but not below, suggesting a switch from linear-viscous to higher-power creep at about that density.

\section{Crevassing}

We interpret the fracture traces observed below $50 \mathrm{~m}$ as incipient crevasses that did not fill with snow before they closed and healed. The numerous fractures observed, exhibiting some cross-cutting relations and reactivation of previously formed fractures, show that opening and closing of fractures were repeated frequently. Alternate stretching and compression during "accordion-like" flow over sticky spots may have been involved (Anandakrishnan and others, 2001). If the crevasses opened to significant width at the surface (more than a few millimeters?) and to significant depth (more than perhaps $1 \mathrm{~m}$ below the surface?), this would have enabled introduction of finer-grained drift snow to regions of coarser-grained firn or ice, and this fill now would be evidenced as a zone as wide as (or wider than, allowing for along-flow stretching) the original crevasse with anomalously numerous and small bubbles. No such zones are recognized among these fracture traces. The small bubbles along the central planes of the healed fractures are in a plane only a single bubble wide and are more consistent with mismatch of opposing sides during closure. It thus appears that the fractures either did not reach the surface, or did not open sufficiently to capture drift snow. Our data are consistent with the suggestion by Nath and Vaughan (2000) that crevassing initiates at depth (approximately $10 \mathrm{~m}$ ?) and propagates upwards as well as downwards. We also support the suggestion by Whillans and others (2001) that fractures in the ice stream often heal followed by re-fracturing.

The lack of healed fracture traces in the deepest part of the core (Fig. 5b) may indicate that this ice had been buried below the depth of crevassing before entering the ice stream. Assuming that the fracturing occurred especially in the upper $10-20 \mathrm{~m}$, has been buried by the accumulation since the slow-down of the ice stream, and was transported by active flow at a few hundred meters per year before slowdown with accompanying longitudinal strain, the most abundant fractures would have formed a few hundred $\mathrm{km}$ up-glacier, and may correspond to intense strain at the onset of streaming flow.

Apparent splitting and rejoining of some fractures isolating lozenge-shaped regions of ice suggests at least a small component of shear along the fractures (cf. Engelder and others, 1993, section 8; Schulson and others, 1999). The bubbles along the central planes of fractures indicate that a mismatch developed between the sides before healing, perhaps resulting from at least slight shear motion, or alternatively, vapor transported water from the exposed surfaces of the fracture, changing the shapes of the opposing faces before the fracture closed. The bubble-free, few-millimeter-thick zones flanking these bubbly planes may represent vapor-diffusion closure of bubbles, or else some sort of process zone of enhanced strain in high-stress regions around bubbles during fracture-tip propagation (e.g. Engelder and others, 1993, section 7).

Melt layers extend back through the Holocene in the Siple Dome core (personal communication from S.B.Das and R.B. Alley, 2000, http://igloo.gsfc.nasa.gov/wais/abstracts00/Das. htm). The absence of melt layers from the deeper and older parts of the UpC core is consistent with this ice having been transported from higher, colder regions farther inland.

\section{DISGUSSION}

Interpretation of physical data from ice cores is rarely unique, but the datasets presented here are consistent with rapid ice streaming followed by abrupt shut-down of the central region of Ice Stream C. The core from UpC indicates that vigorous ice-stream flow transported the deeper ice sampled at the UpC site from well upstream and "inland" where less surface melting occurs, and produced extensive opening and healing of fractures, especially near the onset of the ice stream. Most fractures did not open significantly at the surface to allow filling and were likely subsurface features. The active ice-stream flow produced dipping layers through strain or through rapid transport of ice across accumulationrate gradients perhaps linked to surface topography (Vaughan and others, 1999). This flow also produced high deviatoric stresses, causing rapid strain recorded in fractures, elongated bubbles, recrystallized ice (based on textures and $c$-axis fabrics; analysis in progress), and an open surface crevasse that captured drift snow. These high stresses enhanced densification for ice-stream firn at high densities. This situation was terminated by a rapid shut-down of the streaming ice motion within about a decade of the year 1830, followed by burial of the ice-stream ice by "normal", horizontally layered and largely undeformed firn. Narrowing before shut-down as reported by Jacobel and others (2000) need not have affected the central region, so there is no necessary conflict between our observations and their conclusions about the behavior of the margins of Ice Stream C.

\section{ACKNOWLEDGEMENTS}

We thank J.J. Fitzpatrick, G. Hargreaves and others at NICL for core processing and archival, PICO for core recovery, K. C. Taylor and G.W. Lamorey for ECM and DEP data, J.J. Fitzpatrick for thin-section imagery, L. A. Wilen for intercomparisons in thin-section analysis, and other colleagues in the WAIS (West Antarctic ice sheet) and WAISCORES efforts. This research was supported by grants from the U.S. National Science Foundation Office of Polar Programs.

\section{REFERENGES}

Alley, R. B. 1987. Firn densification by grain-boundary sliding: a first model. f. Phys. (Paris), 48, Colloq. C1, 249-254. (Supplément au 3.)

Alley, R. B. 1988. Concerning the deposition and diagenesis of strata in polar firn. F. Glaciol., 34(118), 283-290.

Alley, R. B. and C. R. Bentley. 1988. Ice-core analysis on the Siple Coast of West Antarctica. Ann. Glaciol., 11, 1-7.

Alley, R. B. and R. A. Bindschadler. 2001. The West Antarctic ice sheet and sea-level change. In Alley, R. B. and R. A. Bindschadler, eds. TheWest Antarctic ice sheet: behavior and environment. Washington, DC, American Geophysical Union, 1-11. (Antarctic Research Series 77.)

Alley, R. B. and J. J. Fitzpatrick. 1999. Conditions for bubble elongation in cold ice-sheet ice. 7. Glaciol., 45(149), 147-153.

Anandakrishnan, S. and R. B. Alley. 1997. Stagnation of Ice Stream C, West 
Antarctica by water piracy. Geophys. Res. Lett., 24(3), 265-268.

Anandakrishnan, S., R. B. Alley, R.W. Jacobel and H. Conway. 2001. The flow regime of Ice Stream $\mathrm{C}$ and hypotheses concerning its recent stagnation. In Alley, R. B. and R. A. Bindschadler, eds. The West Antarctic ice sheet: behavior and environment. Washington, DC, American Geophysical Union, 283-294. (Antarctic Research Series 77.

Duval, P. 1985. Grain growth and mechanical behaviour of polar ice. Ann. Glaciol., 6, 79-82.

Ebinuma, T. and N. Maeno. 1985. Experimental studies on densification and pressure-sintering of ice. Ann. Glaciol., 6, 83-86.

Engelder, T., M. P. Fischer and M. R. Gross. 1993. Geological aspects of fracture mechanics. Boulder, CO, Geological Society of America. (Short Course Notes.)

Gow, A. J. 1968. Bubbles and bubble pressures in Antarctic glacier ice. F. Glaciol., 7(50), 167-182.

Gow, A. J. 1975. Time-temperature dependence of sintering in perennial isothermal snowpacks. International Association of Hydrological Sciences Publication 114 (Symposium at Grindelwald 1974 - Snow Mechanics), 25-41.

Jacobel, R.W., T. A. Scambos, N. A. Nereson and C. F. Raymond. 2000. Changes in the margin of Ice Stream C, Antarctica. F. Glaciol., 46(152), 102-110.

Kamb, B. 2001. Basal zone of the West Antarctic ice streams and its role in lubrication of their rapid motion. In Alley, R. B. and R. A. Bindschadler, eds. The West Antarctic ice sheet: behavior and environment. Washington, DC, American Geophysical Union, 157-199. (Antarctic Research Series 77.)

Moore, J. C. and J. G. Paren. 1987. A new technique for dielectric logging of Antarctic ice cores. 7. Phys. (Paris), 48, Colloq. C1, 155-160. (Supplément au 3.)

Nath, P. C. and D. G. Vaughan. 2000. Sub-surface crevasse formation on ice streams. Filchner-Ronne Ice Shelf Programme Report 13, 40-46.

Palais, J. M., S. Germani and G. A. Zielinski. 1992. Inter-hemispheric transport of volcanic ash from a 1259 A.D. volcanic eruption to the Greenland and Antarctic ice sheets. Geophys. Res. Lett., 19(8), 801-804.

Price, S. F., R. A. Bindschadler, C. L. Hulbe and I. R. Joughin. 2001. Poststagnation behavior in the upstream regions of Ice Stream C, West Antarctica. F. Glaciol., 47(157), 283-294.

Retzlaff, R. and C. R. Bentley. 1993. Timing of stagnation of Ice Stream C, West Antarctica, from short-pulse radar studies of buried surface crevasses. 7. Glaciol., 39(133), 553-561.

Retzlaff, R., N. Lord and C. R. Bentley. 1993. Airborne-radar studies: Ice Streams A, B and C, West Antarctica. F. Glaciol., 39(133), 495-506.

Schulson, E. M., D. Iliescu and C. E. Renshaw. 1999. On the initiation of shear faults during brittle compressive failure: a new mechanism. 7. Geophys. Res., 104(Bl), 695-705.

Spencer, M. K., R. B. Alley and T. T. Creyts. 2001. Preliminary firn-densification model with 38-site dataset. F. Glaciol., 47(159), 671-676.

Taylor, K. and 6 others. 1992. Ice-core dating and chemistry by direct-current electrical conductivity. 7. Glaciol., 38(130), 325-332.

Tulaczyk, S. M., B. Kamb and H. F. Engelhardt. 2000. Basal mechanics of Ice Stream B, West Antarctica. II. Undrained-plastic-bed model. f. Geophys. Res., 105(B1), 483-494.

Vaughan, D. G., H. F. J. Corr, C. S. M. Doake and E. D. Waddington. 1999. Distortion of isochronous layers in ice revealed by ground-penetrating radar. Nature, 398(6725), 323-326.

Whillans, I. M., C. R. Bentley and C. J. van der Veen. 2001. Ice Streams B and C. In Alley, R. B. and R. A. Bindschadler, eds. The West Antarctic ice sheet: behavior and environment. Washington, DC, American Geophysical Union, 257-281. (Antarctic Research Series 77.) 